\title{
PENGARUH KUALITAS PELAYANAN ECERAN (RETAIL MARKETING MIX APPLICATION) TERHADAP KEPUASAN KONSUMEN
}

\author{
THE EFFECT OF RETAIL SERVICE MIX (RETAIL MARKETING MIX \\ APPLICATION) ON CUSTOMER SATISFACTION
}

\author{
Amandin \\ STIE Prabumulih \\ amandinypp50@gmail.com
}

\begin{abstract}
Given how important the role of service quality is for the life of an organization or company to try to increase its potential, so that the quality and quantity of these services can compete or at least be able to keep up with the pace of competition in the business world. This study aims to determine the Effect of Retail Service Quality (Retail Marketing Mix Application) on Consumer Satisfaction in Alfamart Jl. Raya PalembangPrabumulih, Gelumbang District, Muara Enim Regency. The method used in this study is a survey method. The data collected consists of primary data and secondary data. Primary data obtained through the interview method that is equipped with a questionnaire that has been prepared. Secondary data were obtained from related companies, as well as several library sources in the form of journals and books relating to this research. And the research design used is causal associative design. In this research, what will be analyzed is the effect of service quality consisting of reliability, responsiveness, assurance, empathy, tangible. The results showed the calculation of the coefficient of determination (R2) was used to determine what percentage of the dependent variable variation could be explained by the variation of the independent variables. From the SPSS output display, the summary model of customer satisfaction is influenced or explained by variations in the five dimensions of service quality, namely physical evidence, reliability, responsiveness, assurance, care. Therefore it can be concluded that the retail marketing mix delivered well by the company can increase customer satisfaction.
\end{abstract}

Keywords: Service Quality, Consumer Satisfaction

\begin{abstract}
ABSTRAK
Mengingat betapa pentingnya peran kualitas pelayanan bagi kehidupan suatu organisasi atau perusahaan untuk berupaya meningkatkan potensi yang dimiliki, agar kualitas dan kuantitas pelayanan tersebut dapat bersaing atau setidaknya mampu mengimbangi laju persaingan di dunia usaha. Penelitian ini bertujuan untuk mengetahui Pengaruh Kualitas Pelayanan Eceran (Retail Marketing Mix Application) Terhadap Kepuasan Konsumen Di Alfamart Jl. Raya Palembang-Prabumulih Kecamatan Gelumbang Kabupaten Muara Enim. Metode yang digunakan dalam penelitian ini adalah metode survey. Data yang dikumpulkan terdiri dari data primer dan data sekunder. Data primer diperoleh melalui metode wawancara yang dilengkapi dengan kuisioner yang telah disiapkan. Data sekunder diperoleh dari perusahaan yang terkait, serta beberapa sumber pustaka baik berupa jurnal maupun buku yang berhubungan dengan penelitian ini. Dan desain penelitian yang digunakan adalah desain asosiatif kausal. Dalam penelitian ini, yang
\end{abstract}


akan dianalisis adalah pengaruh kualitas pelayanan yang terdiri dari kehandalan (reliability), daya tanggap(responsivess), jaminan (assurance), empati (empathy), berwujud (tangible). Hasil penelitian menunjukkan perhitungan koefisien determinasi $\left(\mathrm{R}^{2}\right)$ digunakan untuk mengetahui berapa persen variasi variabel dependen dapat dijelaskan oleh variasi variabel independen. Dari tampilan output SPSS model summary kepuasan konsumen dipengaruhi atau dijelaskan variasi dari kelima dimensi kualitas pelayanan yaitu bukti fisik, kehandalan, daya tanggap, jaminan, kepedulian. Oleh sebab itu dapat disimpulkan bahwa bauran pemasaran retail yang tersampaikan secara baik oleh perusahaan dapat meningkatkan kepuasan pelanggan.

Kata Kunci : Kualitas Pelayanan, Kepuasan Konsumen

\section{PENDAHULUAN}

Dunia bisnis dalam era globalisasi seperti yang tengah terjadi sekarang ini berada dalam situasi yang serba tidak menentu dan sulit sekali untuk diprediksi dalam menghadapi tantangan. Secara internal, organisasi menghadapi masalah produktivitas, mutu, biaya, waktu, pelayanan, keselamatan, lingkungan dan perilaku pekerja yang semakin hari semakin berat. Sementara secara eksternal, organisasi mendapat tekanan bertubitubi dari berbagai penjuru antara lain dari pelanggan, pemasok, kompetitor, lembaga swadaya masyarakat, pemerintah dan berbagai macam perubahan yang tidak terduga.

Mengingat betapa pentingnya peran kualitas pelayanan bagi kehidupan suatu organisasi atau perusahaan untuk berupaya meningkatkan potensi yang dimiliki, agar kualitas dan kuantitas pelayanan tersebut dapat bersaing atau setidaknya mampu mengimbangi laju persaingan di dunia usaha. Pelayanan pelanggan ini sangat penting artinya bagi kehidupan suatu perusahaan, karena tanpa pelanggan, maka tidak akan terjadi transaksi jual beli diantara keduanya. Untuk itu kegiatan pelayanan perusahaan haruslah berorientasi pada kepuasan konsumen. Kualitas pelayanan karyawan terhadap kepuasan konsumen dapat memberikan kontribusi kepada perusahaan dalam meningkatkan pendapatan jangka panjangnya adalah pada sejauh mana kemampuan perusahaan atau organisasi melayani atau memberi pelayanan secara maksimal kepada para pelanggannya secara sistematis dan terprogram yang tidak melanggar nilai-nilai etika dalam sebuah bisnis.

Pada industri atau bisnis yang berorientasi pada pelanggan, maka tidak dapat dihindari bahwa kualitas pelayanan menjadi satu-satunya faktor penentu dari eksistensi perusahaan atau industri tersebut dalam terlibat di industri atau bisnis yang penuh dengan persaingan, karena jika kualitas pelayanan tidak diperhatikan, maka konsekuensinya pelanggan akan berpindah kepada industri atau bisnis lain yang sejenis yang lebih memberikan pelayanan yang memuaskan bagi konsumennya.

Dalam melihat dimensi apa saja yang mempengaruhi kualitas sebuah pelayanan dalam bisnis, khususnya pada sektor jasa terhadap kepuasan konsumen, penulis melihat bahwa dimensi kualitas pelayanan seperti dibawah ini : Bukti fisik, Kehandalan, Ketanggapan, Jaminan, Empati

Menurut Ma'ruf (2012) pengertian ritel adalah kegiatan usaha menjual barang atau jasa kepada 
perorangan untuk keperluan diri sendiri, keluarga atau rumah tangga. Terkadang orang-orang berpikir bahwa retailing hanya melakukan penjualan produk di toko. Jasa yang ditawarkan oleh dokter gigi juga dapat disebut retailing, tukang salon, maupun penyewaan komik. Usaha eceran adalah suatu usaha yang kegiatannya menyangkut penjualan barang atau jasa secara langsung kepada konsumen untuk penggunaan pribadi dan nir-bisnis (Kotler \& Armstrong 2012).

Besarnya pasar minimarket menjadikan pemain utama, Alfamart dan Indomaret semakin mengukuhkan sayapnya di bisnis ini. Alfamart berusaha mendekatkan diri ke konsumen lewat tempat - tempat potensial dari sisi kelayakan bisnis. Tak bisa dipungkiri, persaingan Alfamart dan Indomaret memang jelas terlihat dan makin sengit ketika banyak dijumpai gerai mereka yang berdekatan. Dimana ada Indomaret, disitu ada pula Alfamart seperti kasus yang terjadi di Indomaret dan Alfamart di Jl. Raya Palembang-Prabumulih. Dari sisi layanan, keduanya menjadikan gerai gerainya bukan hanya sebagai tempat belanja belaka, tapi juga menawarkan layanan dan kualitas produk yang Iebih baik (dibandingkan pasar tradisional).

Alfamart menerapkan bauran pemasaran eceran (retail marketing mix) dalam kegiatan bisnisnya seperti mempertimbangkan store location yang tepat, product characteristic dengan memfokuskan pada barang keperluan sehari - hari, customer service seperti disediakan suara pelanggan dan karyawan yang siap melayani dan membantu pengunjung, retail communication dengan adanya katalog dan keanggotaan melalui program kartu belanja, in store ambience seperti alunan musik dan adanya kenyamanan ruangan (air conditioner), retail price consideration mempertimbangkan harga eceran pesaing dalam menetapkan harga dan menetapkan harga khusus, undian berhadiah maupun hadiah langsung, store design desain eksterior dibuat menarik dengan adanya etalase sedangkan desain interior mempunyai keunikan dengan barang - barang tertentu yang dijual dikelompokan pada tiap rak sesuai fungsi dan manfaatnya, visual merchandising seperti terdapat beberapa produk baru atau promo yang ditempatkan di rak dengan dilengkapi brosur dan poster - poster dengan pelayanan simpatik.

Persaingan ini juga berlaku di Alfamart Jl. Raya PalembangPrabumulih Gelumbang dimana terdapat gerai Alfamart yang berseberangan dengan Indomaret, terdapat 1 Indomaret dan 1 gerai minimarket, selain itu terdapat beberapa warung dan toko tradisional disekitar lokasi penelitian, letak pasar tradisional juga berada tidak jauh dari lokasi penelitian. Hal tersebut merupakan masalah yang dihadapi Alfamart $\mathrm{Jl}$. Raya Palembang-Prabumulih Gelumbang yang merupakan lokasi penelitian untuk memperebutkan konsumen dan menciptakan kepuasan konsumen.

Kepuasan konsumen merupakan kunci sukses perusahaan untuk dapat memenangkan persaingan terutama dalam bisnis ritel. Maka strategi penerapan bauran pemasaran eceran (retail marketing mix application) antara perusahaan ritel yang satu dengan yang lain pun berbeda.

Konsumen adalah nyawa dari perusahaan karena itu perusahaan harus memperhatikan kualitas pelayanan yang diberikan kepada konsumen. Layanan yang baik menjadi salah satu syarat kesuksesan dalam perusahaan. Kualitas pelayanan sering diartikan sebagai perbandingan antara layanan yang 
diharapkan dengan layanan yang diterima secara nyata. Layanan (service) adalah sebuah kegiatan, manfaat, atau kepuasan untuk diberikan yang pada dasarnya tidak berwujud dan tidak mengakibatkan kepemilikan apapun (Kotler \& Amstrong, 2012). Kualitas pelayanan merupakan komponen penting dalam persepsi konsumen, juga sangat penting dalam pengaruhnya terhadap kepuasan konsumen. Semakin baik kualitas maka jasa yang diberikan maka akan semakin baik pula citra jasa tersebut dimata konsumen.

Parasuraman, V.L

mengidentifikasikan lima dimensi yang digunakan oleh konsumen dalam mengevaluasi kualitas dalam jasa pelayanan yang antara lain adalah bukti fisik, Kehandalan, Daya Tanggap, Jaminan, Perhatian.

1. Bukti fisik, meliputi fasilitas fisik, perlengkapan, personilnya dan sarana komunikasi.

2. Kehandalan, yaitu kemampuan untuk menghasilkan kinerja pelayanan yang dijanjikan secara akurat dan pasti. Hal ini berarti bahwa pelayanan harus tepat waktu dan dalam spesifikasi yang sama, tanpa kesalahan, kapanpun pelayanan tersebut diberikan.

3. Daya Tanggap, yaitu bisa menjawab kebutuhan atau bisa diartikan dengan kemauan untuk menolong konsumen dan memberikan pelayanan yang cepat.

4. Jaminan, meliputi pengetahuan dan rasa hormat para karyawan dan kemampuan mereka berarti adanya jaminan tentang kepastian pelayanan yang diberikan.

5. Perhatian, yaitu adanya penjiwaan dan perhatian secara pribadi terhadap konsumen.

Untuk menentukan kebutuhan dan keinginan pelanggan yang akan dipuaskan bukanlah hal yang mudah, hal ini disebabkan karena kebutuhan dan keinginan pelanggan selalu mengalami perubahan dari waktu ke waktu. Jika pelanggan merasa puas, maka ada kecenderungan untuk melakukan pembelian ulang

Kotler (2010), customer satisfaction is a person's feelings of pleasure or disappointment resulting from comparing a product perceived performances (or outcome) in relation to his or her expectations. Kepuasan konsumen atau pelanggan dapat diartikan sebagai perasaan senang atau kecewa (ketidakpuasan) seseorang setelah membandingkan kinerja (performance) produk dengan apa yang diharapkan (expectation).

\section{METODEPENELITIAN}

Untuk memperoleh data-data yang dibutuhkan maka penulis mengadakan penelitian pada Alfamart yang terletak di. Jalan Raya PalembangPrabumulih Kecamatan Gelumbang Kabupaten Muara Enim. Penelitian yang dilakukan ini direncanakan selama 6 (satu) bulan, yakni dari bulan Maret sampai dengan bulan Oktober 2018.

Dalam melakukan penelitian selalu dihadapkan pada sumber data tertentu yang diharapkan dapat memberikan informasi dan keterangan yang berkaitan dengan masalah yang diteliti.Adapun sumber data dalam penelitian sering disebut dengan populasi penelitian. Pengertian populasi menurut Umar (2012) adalah : "populasi diartikan sebagai kumpulan elemen yang mempnyai karakteristik tertentu yang sama dan mempunyai kesempatan yang sama untuk dipilih menjadi anggota sampel". Adapun pengertian sampel menurut Umar (2012) adalah sebagai berikut :"sampel adalah bagian dari populasi".

Menurut PT. Sumber Alfamart Trijaya (alfamart), jumlah rata-rata 
pengunjung atau konsumen perminggu adalah 280 orang dalam bulan maret 2018. Penulis menggunakan angka ini sebagai jumlah populasi konsumen PT. Sumber Alfamart Trijaya (Alfamart). Kemudian untuk menghitung sampel yang dibutuhkan dapat ditentukan dengan rumus yang di kemukakan oleh Slovin yang dikutip oleh Umar (2012).

Rumus :

$\mathrm{n}=$ Ukuran Sampel

$$
\mathbf{n}=\mathbf{N} /(\mathbf{1}+\mathbf{N . e 2})
$$

$\mathrm{N}=$ Ukuran Populasi

$\mathrm{e}=$ Persen keloggaran ketidaktelitian karena kesalahan pengambilan smpel yang

masih dapat ditolerir atau diinginkan. Penulis menggunakan $10 \%$.

$$
\begin{gathered}
\mathrm{n}=280 /(1+280 \times 0,1 \times 0,1) \\
\mathrm{n}=73,68
\end{gathered}
$$

dengan batas kelonggaran kerena ketidaktelitian sebesar $10 \%$, oleh karena itu dalam penelitian ini akan diambil sampel sebesar 80 orang/responden (pembulatan dari 73,68) yang seluruhnya berada di Kecamatan Gelumbang.

Sedangkan untuk teknik pengambilan sampel menggunakan metode accidental sampling. Dimana menurut Arikunto (2012) accidental sampling adalah mengambil responden sebagai sampel berdasarkan kebetulan, yaitu siapa saja yang secara kebetulan bertemu dengan peneliti dapat digunakan sebagai sampel bila orang yang kebetulan ditemui cocok sebagai sumber data. Kriteria Sampel; 1) konsumen yang berbelanja di alfamart, 2) Frekuensi belanja dari 3 kali

Untuk mencari data dan keterangan yang diperlukan digunakan teknik sebagai berikut:

1. Liberary Research, yaitu dengan mencari dan mengumpulkan data dari literatur yang ada hubungannya dengan masalah yang diteliti.
2. Field Research, yaitu penelitian yang dilakukan dilapangan, datanya diperoleh dengan cara :

a. Menggunakan daftar pertanyaan (kuesioner) yang telah dipersiapkan terlebih dahulu

b. Wawancara, yaitu mengajukan pertanyaan secara lisan dan langsung

c. Observasi, yaitu teknik pengumpulan data dengan cara pengamatan langsung terhadap obyek yang diteliti

Data yang terkumpul akan dianalisis dengan menggunakan teknik analisis statistik dengan menggunakan program SPSS. Analisis regresi berganda untuk menghitung besarnya pengaruh secara kuantitatif dari suatu perubahan kejadian (variable $\mathrm{x}$ ) terhadap kejadian lainnya (variable y) dimana rumus statistik yang digunakan adalah Linier Multiple Regression (regresi linier berganda).

Dalam penelitian ini, analisis regresi berganda berperan sebagai teknik statistik yang digunakan untuk menguji ada tidaknya pengaruhkualitas pelayanan karyawan (X) yang terdiri dari : kehandalan (reliability), daya tanggap(responsivess), jaminan (assurance), empati (empathy), berwujud (tangible) terhadap kepuasan konsumen (Y), yang dikutip dari Sugiyono (2009) dengan menggunakan rumus sebagai berikut :

$$
\mathrm{Y}=\mathrm{b} 0+\mathrm{b} 1 . \mathrm{X} 1+\mathrm{b} 2 . \mathrm{X} 2+
$$

b3.X3 + b4X4 + b5X5 + e

Dimana :

$\mathrm{Y}=$ Kepuasan konsumen

b0 $=$ Nilai Constan/Reciprocel

$\mathrm{X}_{1}=$ Kehandalan

$\mathrm{X}_{2}=$ Daya tanggap

$\mathrm{X}_{3}=$ Jaminan

$\mathrm{X}_{4}=$ Empati

$\mathrm{X}_{5}=$ Berwujud (Bukti Fisik)

b1, b2, b3, b4, b5 = koefisien regresi

$\mathrm{e}=$ standart error 
Prosedur di atas dipakai dengan menggunakan pedoman yang paling umum digunakan yaitu skala Likert. Menurut Kinnear (Umar, 2012), skala Likert berhubungan dengan pernyataan tentang sikap seseorang terhadap sesuatu, misalnya setuju-tidak setuju, senang-tidak senang, dan baik-tidak baik.Responden kemudian di minta mengisi pernyataan dalam skala ordinal berbentuk verbal dalam jumlah kategori tertentu.

Data yang berhasil dikumpulkan dari kuesioner selanjutnya akan diukur dengan pengukuran data ordinal dengan bobot hitung sampai 5, dengan kategori:

a. Sangat setuju dengan point 5 .

b. Setuju dengan point 4 .

c. Kurang setuju dengan point 3 .

d. Tidak setuju dengan point 2 .

e. Sangat tidak setuju dengan point 1 .

\section{Analisis Koefisien Determinasi (R2)}

Selanjutnya berdasarkan hasil regresi berganda tersebut, maka selanjutnya dapat dianalisis koefisien determinasi (R) yaitu koefisien determinasi parsial untuk mengukur secara terpisah dampak variabel bebas $\mathrm{X}_{1}, \mathrm{X}_{2}, \mathrm{X}_{3}, \mathrm{X}_{4}, \mathrm{X}_{5}$ terhadap variabel $\mathrm{Y}$, dengan bantuan program SPSS pada computer.

\section{Uji F (Uji Serempak)}

Uji ini digunakan untuk mengetahui pengaruh secara bersamasama variabel bebas secara signifikan terhadap variabel terikat.Dimana Fhitung > Ftabel, maka Hi diterima atau secara bersama-sama variabel bebas dapat menerangkan variabel terikatnya secara serentak. Sebaliknya apabila Fhitung > Ftabel, maka Ho diterima secara bersama-sama variabel bebas tidak memiliki pengaruh terhadap variabel terikat.

\section{Uji T (Uji Parsial)}

Uji ini digunakan untuk mengetahui apakah masing-masing variable bebasnya secara sendiri-sendiri berpengaruh secara signifikan terhadap variable terikatnya. Dimana ttabel > thitung, Ho diterima.Dan jika ttabel > thitung, Hi diterima (Setiaji, 2014).

\section{Analisis Koefisien Determinasi $\left(\mathbf{R}^{\mathbf{2}}\right)$}

Analisis koefisien determinasi digunakan untuk mengetahui presentase sumbangan pengaruh variabel bebas secara bersama-sama terhadap variabel terikat. Koefisien determinasi menunjukkan seberapa besar presentase variasi variabel bebas yang digunakan dalam model mampu menjelaskan variasi variabel terikat. $\mathrm{R}^{2}$ $=0$, maka tidak ada sedikitpun presentase sumbangan pengaruh yang diberikan variabel bebas terhadap variabel terikat. Sebaliknya $\mathrm{R}^{2}=1$, maka presentase sumbangan pengaruh yang diberikan variabel bebas terhadap variabel terikat adalah sempurna, atau variasi variabel bebas yang digunakan dalam model menjelaskan $100 \%$ variasi variabel terikat. Setiaji (2014)

\section{HASIL DAN PEMBAHASAN Uji Validitas}

Pengujian validitas dilakukan dengan menggunakan metode Analisis korelasi. Perhitungan dilakukan dengan bantuan program SPSS. Nilai signifikansi yang berada di bawah 0,05 menunjukkan sebagai item yang valid. Pengujian validitas selengkapnya dapat dilihat pada Tabel berikut ini:

\begin{tabular}{lcccc}
\multicolumn{5}{c}{ Tabel 1 Hasil Uji Validitas } \\
\hline $\begin{array}{c}\text { Variabe } \\
1\end{array}$ & Item & $\mathrm{r}_{\text {hitung }}$ & $\mathrm{r}_{\text {tabel }}$ & Keterangan \\
\hline \multirow{3}{*}{$\mathrm{X} 1$} & 1 & 0,577 & 0,317 & Valid \\
\cline { 2 - 5 } & 2 & 0,716 & 0,317 & Valid \\
\cline { 2 - 5 } & 3 & 0,888 & 0,317 & Valid \\
\cline { 2 - 5 } & 4 & 0,489 & 0,317 & Valid \\
\cline { 2 - 5 } & 5 & 0,864 & 0,317 & Valid \\
\hline
\end{tabular}




\begin{tabular}{|c|c|c|c|c|}
\hline \multirow{5}{*}{$\mathrm{X} 2$} & 6 & 0,416 & 0,317 & Valid \\
\hline & 7 & 0,518 & 0,317 & Valid \\
\hline & 8 & 0,848 & 0,317 & Valid \\
\hline & 9 & 0,527 & 0,317 & Valid \\
\hline & 10 & 0,778 & 0,317 & Valid \\
\hline \multirow{5}{*}{ X3 } & 11 & 0.546 & 0,317 & Valid \\
\hline & 12 & 0.64 & 0,317 & Valid \\
\hline & 13 & 0.755 & 0,317 & Valid \\
\hline & 14 & 0,495 & 0,317 & Valid \\
\hline & 15 & 0,810 & 0,317 & Valid \\
\hline \multirow{5}{*}{$\mathrm{X} 4$} & 16 & 0,589 & 0,317 & Valid \\
\hline & 17 & 0,654 & 0,317 & Valid \\
\hline & 18 & 0,825 & 0,317 & Valid \\
\hline & 19 & 0,539 & 0,317 & Valid \\
\hline & 20 & 0,823 & 0,317 & Valid \\
\hline \multirow{5}{*}{ X5 } & 21 & 0,554 & 0,317 & Valid \\
\hline & 22 & 0,636 & 0,317 & Valid \\
\hline & 23 & 0,866 & 0,317 & Valid \\
\hline & 24 & 0,496 & 0,317 & Valid \\
\hline & 25 & 0,853 & 0,317 & Valid \\
\hline \multirow{5}{*}{$\mathrm{Y}$} & 1 & 0,548 & 0,317 & Valid \\
\hline & 2 & 0,715 & 0,317 & Valid \\
\hline & 3 & 0,866 & 0,317 & Valid \\
\hline & 4 & 0,561 & 0,317 & Valid \\
\hline & 5 & 0,849 & 0,317 & Valid \\
\hline
\end{tabular}

Sumber : Data primer yang diolah, 2018

Hasil uji validitas pada Tabel di atas dapat diketahui bahwa semua indikator berkorelasi signifikan dengan total skor, ditunjukan nilai rhitung > dari rtabel. Korelasi yang signifikan antara skor indikator dengan total skor menunjukan bahwa indikator yang digunakan baik dari variabel bebas (X) maupun dari variabel terikat (Y) dapat mengukur variabel yang diteliti, semua indikator yang digunakan untuk mengukur variabel-variabel yang digunakan dalam penelitian ini mempunyai nilai korelasi yang lebih besar dari 0,317. Dari hasil tersebut menunjukkan bahwa semua indikator tersebut adalah valid.

\section{Uji Reliabilitas}

Pengujian reliabilitas dalam penelitian ini adalah dengan menggunakan rumus Cronbach Alpha. Hasil pengujian reliabilitas untuk masing-masing variabel yang diringkas pada tabel 4.12 berikut ini:

Tabel 2 Hasil Pengujian Reliabilitas

\begin{tabular}{ccc}
\hline Variabel & Alpha & Keterangan \\
\hline Tangible / & 0,761 & Reliabel \\
\hline Reliability / & 0,834 & Reliabel \\
\hline Resvonsivene & 0,840 & Reliabel \\
\hline Assurance / & 0,862 & Reliabel \\
\hline Empathy / & 0,857 & Reliabel \\
\hline Keputusan & 0,810 & Reliabel \\
\hline
\end{tabular}

Sumber : Data primer yang diolah, 2018

Hasil uji reliabilitas tersebut menunjukkan bahwa semua variabel mempunyai koefisien Alpha yang cukup besar yaitu diatas 0,6 sehingga dapat dikatakan semua konsep pengukur masing-masing variabel dari kuesioner adalah reliabel yang berarti bahwa kuesioner yang digunakan dalam penelitian ini merupakan kuesioner yang handal.

\section{Analisis Regresi Linier Berganda}

Analisis regresi linier berganda digunakan dalam penelitian ini dengan tujuan untuk membuktikan hipotesis mengenai pengaruh variabel dimensi- dimensi kualitas pelayanan secara parsial maupun secara bersamasama terhadap kepuasan konsumen. Perhitungan statistik dalam analisis regresi linier berganda yang digunakan dalam penelitian ini adalah dengan menggunakan bantuan program komputer SPSS. Hasil pengolahan data dengan menggunakan program SPSS selengkapnya ada pada lampiran dan selanjutnya dijelaskan pada Tabel berikut ini : 


\section{Tabel 3 Hasil Uji Regresi Linier Berganda}

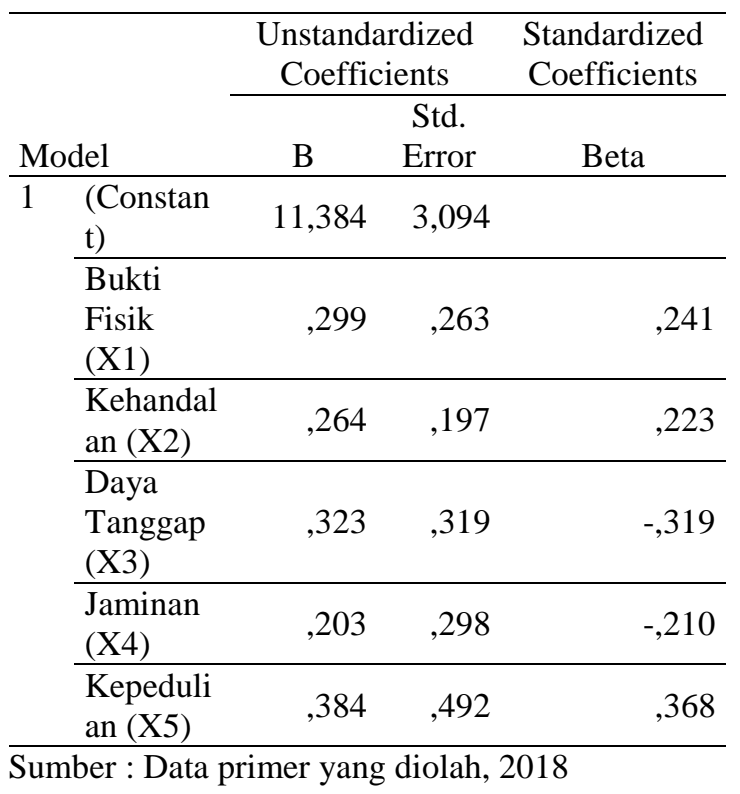

Model persamaan regresi yang dapat dituliskan dari hasil tersebut dalam bentuk persamaan regresi sebagai berikut :

$\mathrm{Y}=11,384+0,299 \mathrm{X} 1+0,264 \mathrm{X} 2+$ $0,323 X 3+0,203 X 4+0,384 X 5+e$

Persamaan regresi tersebut dapat dijelaskan sebagai berikut :

1. Persamaan regresi linear berganda diatas, diketahui mempunyai nilai konstanta sebesar 11,384 dengan tanda positif. Sehingga besaran konstanta menunjukan bahwa jika variabel-variabel independen yaitu bukti fisik, handal, daya tanggap, jaminan dan kepedulian diasumsikan dengan nilai konstan, maka variabel dependen yaitu keputusan masyarakat akan naik sebesar 11,384 $\%$.

2. Nilai koefisien regresi $X 1$ sebesar 0,299 artinya untuk setiap kenaikan 1 skor variabel bukti fisik (X1) akan menaikkan skor kepuasan konsumen (Y) sebesar 0,230.
3. Nilai koefisien regresi X2 sebesar 0,264 artinya untuk setiap kenaikan 1 skorvariabel handal (X2) akan menaikkan skor kepuasan konsumen (Y) sebesar 0,005

4. Nilai koefisien regresi X3 sebesar 0,323 artinya untuk setiap kenaikan 1 skor variabel daya tanggap (X3) akan menaikkan skor kepuasan konsumen (Y) sebesar 0,334

5. Nilai koefisien regresi $\mathrm{X} 4$ sebesar 0,203 artinya untuk setiap kenaikan 1 skor variabel jaminan (X4) akan menaikkan skor kepuasan konsumen (Y) sebesar 0,306.

6. Nilai koefisien regresi X5 sebesar 0,384 artinya untuk setiap kenaikan 1 skor variabel kepedulian (X5) akan menaikkan skor kepuasan konsumen (Y) sebesar 0,393.4

\section{Uji t (Pengujian hipotesis secara parsial)}

Tabel 4. Hasi uji T

\begin{tabular}{lrr}
\hline Variabel & T Statistic & Sig. \\
\hline (Constant) & 3,679 &, 000 \\
\hline Bukti Fisik (X1) & 1,138 &, 059 \\
\hline Kehandalan (X2) & 1,343 &, 000 \\
\hline Daya Tanggap (X3) & $-1,012$ &, 315 \\
\hline Jaminan (X4) & 3,680 &, 008 \\
\hline Kepedulian (X5) &, 782 &, 437 \\
\hline
\end{tabular}

Sumber : Data primer yang diolah, 2018

Untuk menguji keberartian model regresi untuk masing-masing variabel secara parsial dapat diperoleh dengan menggunakan uji t. Berikut akan dijelaskan pengujian masingmasing variabel secara parsial.

\section{Variabel Bukti Fisik}

Hasil pengujian diperoleh nilai $t$ untuk variabel tampilan fisik menunjukkan nilai $\mathrm{t}=1,138$ dengan nilai signifikansi sebesar $0,022<$ 0,05 . Dengan nilai signifikansi di bawah 0,05 tersebut menunjukkan bahwa bukti 
fisik memiliki pengaruh yang signifikan terhadap kepuasan konsumen. Hal ini berarti Hipotesis 1 diterima. Arah koefisien regresi positif berarti bahwa bukti fisik memiliki pengaruh positif yang signifikan terhadap kepuasan konsumen. Semakin baik bukti fisik yang ada akan semakin tinggi pula kepuasan konsumen, sebaliknya semakin tidak baik bukti fisik yang ada semakin rendah pula kepuasan konsumen.

\section{Variabel Kehandalan}

untuk variabel kehandalan menunjukkan nilai $\mathrm{t}=1,343$ dengan nilai signifikansi sebesar 0,003 < 0,05 . Dengan nilai signifikansi di bawah 0,05 tersebut menunjukkan bahwa kehandalan memiliki pengaruh yang signifikan terhadap kepuasan konsumen. Hal ini berarti Hipotesis 2 diterima. Arah koefisien regresi positif berarti bahwa kehandalan memiliki pengaruh positif yang signifikan terhadap kepuasan konsumen. Semakin tinggi kehandalan pelayanan yang diberikan akan semakin tinggi pula kepuasan masyarakat, sebaliknya semakin rendah kehandalan pelayanan yang diberikan semakin rendah pula kepuasan konsumen.

\section{Variabel Daya tanggap}

nilai $\begin{array}{ccc}\text { Hasil pengujian diperoleh } \\ \mathrm{t} & \text { untuk variabel daya }\end{array}$ tanggap menunjukkan nilai $\mathrm{t}=-1,012$ dengan nilai signifikansi sebesar 0,038 $<0,05$. Dengan nilai signifikansi di bawah 0,05 tersebut menunjukkan bahwa daya danggap memiliki pengaruh yang signifikan terhadap kepuasan konsumen. Hal ini berarti Hipotesis 3 diterima. Arah koefisien regresi positif berarti bahwa daya tanggap memiliki pengaruh positif yang signifikan terhadap kepuasan konsumen. Semakin tinggi daya tanggap yang ada akan semakin tinggi pula kepuasan masyarakat, sebaliknya semakin rendah daya tanggap yang ada semakin rendah pula kepuasan pelanggan.

\section{Variabel Jaminan}

Hasil pengujian diperoleh nilai $\mathrm{t}$ untuk variabel jaminan menunjukkan nilai $\mathrm{t}=3,680$ dengan nilai signifikansi sebesar $0,007<0,05$. Dengan nilai signifikansi di bawah 0,05 tersebut menunjukkan bahwa jaminan memiliki pengaruh yang signifikan terhadap kepuasan konsumen. Hal ini berarti Hipotesis 4 diterima. Arah koefisien regresi positif berarti bahwa jaminan memiliki pengaruh positif yang signifikan terhadap kepuasan pelanggan. Semakin besar jaminan yang diberikan akan semakin tinggi pula kepuasan konsumen, sebaliknya semakin rendah jaminan yang diberikan semakin rendah pula kepuasan konsumen.

\section{Variabel kepedulian}

Hasil pengujian diperoleh nilai $\mathrm{t}$ untuk variabel kepedulian menunjukkan nilai $\mathrm{t}=0,782$ dengan nilai signifikansi sebesar $0,009<0,05$. Dengan nilai signifikansi di bawah 0,05 tersebut menunjukkan bahwa kepedulian memiliki pengaruh yang signifikan terhadap kepuasan konsumen. Hal ini berarti Hipotesis 5 diterima. Arah koefisien regresi positif berarti bahwa empati memiliki pengaruh positif yang signifikan terhadap kepuasan konsumen. Semakin besar kepedulian yang diberikan akan semakin tinggi pula kepuasan konsumen, sebaliknya semakin rendah kepedulian yang diberikan semakin rendah pula kepuasan konsumen. 


\section{Uji F}

Hasil perhitungan regresi secara bersama-sama diperoleh pada tabel 4.16 Berikut : Hasil Uji Regresi

\section{Tabel 5. Hasil uji F}

\begin{tabular}{lrrrrr}
\hline \multicolumn{1}{c}{ Model } & \multicolumn{1}{c}{ Sum of } & \multicolumn{3}{c}{ Mean } & \\
Squares & df & Square & \multicolumn{1}{c}{ F } & \multicolumn{1}{c}{ Sig. } \\
\hline 1 Regression & 43,064 & 5 & 8,613 & 2,043 &, $002^{\mathrm{b}}$ \\
\hline Residual & 311,924 & 74 & 4,215 & & \\
\hline Total & 354,987 & 79 & & & \\
\hline
\end{tabular}

Pengujian pengaruh variabel bebas secara bersama-sama terhadap variabel terikatnya dilakukan dengan menggunakan uji F. Hasil perhitungan statistik menunjukkan nilai $\mathrm{F}$ hitung $=$ 2,043 dengan signifikansi sebesar $0,002<0,05$. Dengan nilai signifikansi di bawah 0,05 menunjukkan bahwa secara bersamasama bukti fisik, keandalan, daya tanggap, jaminan, kepedulian dan pembagian kerja mempunyai pengaruh yang positif dan signifikan terhadap kepuasan konsumen, hal ini berarti hipotesis 6 diterima.

\section{Koefisien Determinasi}

Koefisien determinasi ini digunakan untuk mengetahui seberapa besar pengaruh variabel-variabel bebas memiliki pengaruh terhadap variabel terikatnya. Nilai koefisien determinasi ditentukan dengan nilai adjusted $R$ square.

\section{Tabel 6. Koefisien Determinasi}

\begin{tabular}{llrrr}
\hline & & & Adjusted R & $\begin{array}{c}\text { Std. Error of the } \\
\text { Model }\end{array}$ \\
\hline 1 & $\mathrm{R}$ & R Square & \multicolumn{1}{c}{ Square } & \multicolumn{1}{c}{ Estimate } \\
\hline & $.839 \mathrm{a}$ & .851 & .738 & 5.304 \\
\hline
\end{tabular}

Dari tampilan output SPSS model summary besarnya adjusted R2 adalah 0,738. Hal ini berarti $73,8 \%$ kepuasan konsumen dipengaruhi atau dijelaskan variasi dari kelima dimensi kualitas pelayanan yaitu bukti fisik, kehandalan, daya tanggap, jaminan, kepedulian, sedangkan sisanya yaitu $26,2 \%(100 \%-73,8 \%=26,2 \%)$ kepuasan masyarakat dipengaruhi oleh variabel-variabel lainnya yang tidak diteliti dalam penelitian ini (dijelaskan oleh sebab-sebab yang lain diluar model.

Secara umum penelitian ini menunjukkan hasil yang cukup memuaskan. Hasil analisis deskriptif menunjukkan bahwa kualitas pelayanan yang diberikan oleh Alfamart Jl. Raya Palembang-Prabumulih Kecamatan Gelumbang Kabupaten Muara Enim bagian pelayanannya secara umum sudah baik. Hal ini dapat ditunjukkan dari banyaknya tanggapan kepuasan yang tinggi dari responden terhadap kondisi dari masing-masing variabel penelitian. Dari hasil tersebut selanjutnya diperoleh bahwa variabel kualitas pelayanan dalam kelima dimensinya memiliki pengaruh yang positif dan signifikan terhadap kepuasan konsumen. Layanan (service) adalah sebuah kegiatan, manfaat, atau kepuasan untuk diberikan yang pada dasarnya tidak berwujud dan tidak mengakibatkan kepemilikan apapun (Kotler \& Amstrong, 2012). Hal ini dikarenakan bahwa dengan pemberian pelayanan yang berkualitas, maka hal tersebut akan menciptakan kepuasan dalam diri masyarakat.

Hasil penelitian menunjukkan bahwa variabel tampilan fisik memiliki pengaruh yang positif dan signifikan terhadap kepuasan. Hasil ini memberikan bukti empiris bahwa bukti fisik dari penyedia jasa yang ditunjukkan dengan fasilitas, peralatan dan sumber daya manusia sebagai pemberi pelayanan akan menentukan kepuasan konsumen.

$\begin{array}{ccc}\text { Hasil penelitian } & \begin{array}{r}\text { menunjukkan } \\ \text { behandalan }\end{array}\end{array}$ memiliki pengaruh yang positif dan 
signifikan terhadap kepuasan konsumen. Hasil ini memberikan bukti empiris bahwa kehandalan dari penyedia pelayanan yang ditunjukkan dengan kehandalan dalam bentuk kecepatan pelayanan, kemampuan pegawai, dan kehandalan pegawai dalam melayani konsumen dipertimbangkan dalam membentuk kepuasan konsumen.

Hasil penelitian menunjukkan bahwa variabel daya tanggap memiliki pengaruh yang positif dan signifikan terhadap kepuasan konsumen. Hasil ini memberikan bukti empiris bahwa daya tanggap dari penyedia jasa pelayanan yang ditunjukkan dengan kesediaan staf dalam membantu, kesediaan staf dalam memberikan informasi, respon yang cepat dari petugas, dan penyelesaian masalah dengan cepat akan memberikan pengaruh dalam terbentuknya suatu

kepuasan konsumen.

Hasil penelitian menunjukkan bahwa variabel jaminan memiliki pengaruh yang positif dan signifikan terhadap kepuasan. Hasil ini memberikan bukti empiris bahwa jaminan dari penyedia jasa pelayanan akan memberikan peningkatan pada kepuasan konsumen. Hal ini ditunjukkan dengan kemampuan petugas dalam melayani konsumen, petugas yang mempunyai pengetahuan luas dan jaminan keamanan yang diberikan akan memberikan kesan yang lebih baik sehingga meningkatkan kepuasan konsumen.

Hasil penelitian menunjukkan bahwa variabel kepedulian memiliki pengaruh yang positif dan signifikan terhadap kepuasan pelanggan. Hasil ini memberikan bukti empiris bahwa adanya perhatian dari penyedia pelayanan alfamart dalam bentuk perhatian yang sama, adanya layanan yang cepat untuk konsumen yang membutuhkan bantuan, kemampuan komunikasi yang baik, dan kemampuan dalam memenuhi kebutuhan konsumen.

\section{PENUTUP \\ Kesimpulan}

Berdasarkan pada hasil analisis regresi linier berganda yang telah dilakukan pada penelitian ini. Maka dapat ditarik kesimpulan sebagai berikut :

1. Hasil analisis diperoleh bahwa variabel bukti fisik $\left(\mathrm{X}_{1}\right)$ berpengaruh positif terhadap kepuasan konsumen (Y). Dengan demikian Hipotesis 1 yang menyatakan bahwa bukti fisik $\left(\mathrm{X}_{1}\right)$ berpengaruh positif terhadap kepuasan konsumen (Y) dapat diterima.

2. Hasil analisis diperoleh bahwa variabel kehandalan $\left(\mathrm{X}_{2}\right)$ berpengaruh positif terhadap kepuasan konsumen (Y). Dengan demikian Hipotesis 2 yang menyatakan bahwa kehandalan $\left(\mathrm{X}_{2}\right)$ berpengaruh positif terhadap kepuasan konsumen (Y) dapat diterima.

3. Hasil analisis diperoleh bahwa variabel daya tanggap $\left(\mathrm{X}_{3}\right)$ berpengaruh positif terhadap kepuasan konsumen (Y). Dengan demikian Hipotesis 3 yang menyatakan bahwa daya tanggap $\left(\mathrm{X}_{3}\right)$ berpengaruh positif terhadap kepuasan konsumen (Y) dapat diterima.

4. Hasil analisis diperoleh bahwa variabel jaminan $\left(\mathrm{X}_{4}\right)$ berpengaruh positif terhadap kepuasan konsumen (Y). Dengan demikian Hipotesis 4 yang menyatakan bahwa jaminan $\left(\mathrm{X}_{4}\right)$ berpengaruh positif terhadap kepuasan konsumen (Y) dapat diterima. 
5. Hasil analisis diperoleh bahwa variabel kepedulian $\left(\mathrm{X}_{5}\right)$ berpengaruh positif terhadap kepuasan masyarakat (Y). Dengan demikian Hipotesis 5 yang menyatakan bahwa kepedulian $\left(\mathrm{X}_{5}\right)$ berpengaruh positif terhadap kepuasan konsumen (Y) dapat diterima.

6. Hasil analisis diperoleh bahwa variabel bebas (X) secara bersama-sama terhadap variabel terikatnya (Y) dilakukan dengan menggunakan uji $\mathrm{F}$. menunjukkan bahwa secara bersama-sama bukti fisik, keandalan, daya tanggap, jaminan dan kepedulian mempunyai pengaruh yang positif dan signifikan terhadap kepuasan konsumen, hal ini berarti hipotesis 6 dapat diterima.

7. $73,8 \%$ kepuasan konsumen (Y) dapat dipengaruhi oleh variabel bukti fisik $\left(\mathrm{X}_{1}\right)$, kehandalan $\left(\mathrm{X}_{2}\right)$, daya tanggap $\left(\mathrm{X}_{3}\right)$, jaminan $\left(\mathrm{X}_{4}\right)$, kepedulian $\left(\mathrm{X}_{5}\right)$ dan pembagian kerja Sedangkan sisanya yaitu 26,2\% kepuasan pelanggan dipengaruhi oleh variabel-variabel lainnya yang tidak diteliti dalam penelitian ini.

Hasil penelitian ini sejalan dengan hasil penelitian Purwati \& Sherly (2017) dimana seluruh dimensi kualitas pelayanan berpengaruh terhadap kepuasan pelanggan.

\section{Saran}

\section{Saran Untuk Perusahaan}

Berdasarkan kesimpulan yang diperoleh dalam penelitian ini, maka diajukan saran-saran sebagai pelengkap terhadap kualitas pelayanan yang dapat diberikan oleh Alfamart Gelumbang bagian pramuniaga dan kasir sebagai berikut :
2. Disarankan
kepada Alfamart

Gelumbang kualitas sumber daya manusia (SDM) terutama petugas Alfamart J1. Raya Palembang-Prabumulih Kecamatan Gelumbang Kabupaten Muara Enim, karena dengan kualitas SDM yang baik hal ini dapat meningkatkan kualitas pelayanan yang diberikan kepada konsumen

3. Disarankan kepada Alfamart J1. Raya Palembang-Prabumulih Kecamatan Gelumbang Kabupaten Muara Enim terutama bagi petugas bagian pelayanan untuk selalu memberikan, melayani setiap konsumen yang akan berbelanja di Alfamart Jl. Raya PalembangPrabumulih Kecamatan Gelumbang Kabupaten Muara Enim dengan baik.

4. Disarankan kepada Alfamart Jl. Raya Palembang-Prabumulih Kecamatan Gelumbang Kabupaten Muara Enim untuk selalu memperhatikan karyawannya baik dari segi materiil maupun non materiil, karena hal ini dapat memberikan motivasi kepada petugas Alfamart Jl. Raya Palembang-Prabumulih Kecamatan Gelumbang Kabupaten Muara Enim, agar dapat selalu memberikan pelayanan yang berkualitas kepada pelanggannya.

\section{Saran Untuk Penelitian Mendatang}

Untuk penelitian yang akan datang disarankan untuk menambah variabel independen lainnya selain bukti fisik (tangible), kehandalan (reliability), daya tanggap (responsiveness), jaminan (assurance), kepedulian (emphaty) dan yang tentunya dapat mempengaruhi variabel dependen kepuasan konsumen agar lebih melengkapi penelitian ini karena masih ada variabel-variabel independen lain di luar penelitian ini 
yang mungkin bisa mempengaruhi kepuasan konsumen.

\section{DAFTAR PUSTAKA}

Arikunto, Suharsimi. (2012). Prosedur Penelitian Suatu Pendekatan Analisis. Jakarta: Rineka Cipta.

Kotler, Philip Dan Kevin Lane Keller. (2010). Manajemen Pemasaran. Edisi Kedua Belas. Indeks : Jakarta

Kotler dan Amstrong. (2012). Marketing Management 11 th Edition Pearson Education Inc New Jersey.

Ma'ruf, Hendri, (2012). Pemasaran Ritel, Jakarta : Gramedia Pustaka Utama

Parasuraman, V. A. (2011). A Conceptual Model of Service Quality and Its Implication forr Future Reaserch. Service Quality.

Sugiyono. (2009). Metode Penelitian Pendidikan Pendekatan Kuantitatif, Kualitatif, dan $R \& D$. Bandung: ALFABETA.

Setiaji, Bambang, (2014). Panduan Riset dengan Pendekatan Kuantitatif. Surakarta: Program Pascasarjana UMS

Umar, Husein. (2012). Study Kelayakan Bisnis. Edisi Ketiga. Gramedia Pustaka Utama: Jakarta 